\title{
Fire enhances phosphorus availability in topsoils depending on binding properties
}

\author{
Jörg Schaller,,${ }^{1,5}$ Alexander Tischer, ${ }^{2}$ Eric Struyf,${ }^{3}$ Martina Bremer, ${ }^{4}$ Dácil Unzué Belmonte, ${ }^{3}$ \\ AND KARIN POTTHAST ${ }^{2}$ \\ ${ }^{1}$ Institute of General Ecology, Faculty of Environmental Sciences, Technische Universität Dresden, 01737 Tharandt, Germany \\ ${ }^{2}$ Institute of Soil Science and Site Ecology, Faculty of Environmental Sciences, Technische Universität Dresden, \\ 01737 Tharandt, Germany \\ ${ }^{3}$ Ecosystem Management Research Group, Department of Biology, University of Antwerp, Universiteitsplein 1, Antwerp, Belgium \\ ${ }^{4}$ Institute of Plant and Wood Chemistry, Faculty of Environmental Sciences, Technische Universität Dresden, \\ 01737 Tharandt, Germany
}

\begin{abstract}
Fire can have large effects on ecosystems, with phosphorus being highly important in this regard, especially when considering productivity in burned or adjacent ecosystems after fire. Unfortunately, existing data pose contradictions and methodological challenges to assessing $\mathrm{P}$ availability. Here, the impact of fire on topsoil available $\mathrm{P}$ was estimated using three different types of organic soil layers (raw humus from spruce, humus from beech, and peat) and two fire regimes (obtaining black carbon and ash). Our findings suggest a strong fire impact on $\mathrm{P}$ availability, by enhancing available $\mathrm{P}$ during burning to black carbon $(\sim 10$-fold), and to ash $(\sim 2$ - to 7.5 -fold $)$ dependent on calcite content. Fire impact on $\mathrm{P}$ availability is on a similar order of magnitude as mineral weathering and annual $\mathrm{P}$ cycling/ uptake in/by ecosystems. Furthermore, the proportion of available $\mathrm{P}$ in relation to total $\mathrm{P}$ depends on the origin of the organic soil layers. When related to the remaining mass after burning, as is commonly done, $\mathrm{P}$ availability can be overestimated by up to $1400 \%$. Results from this study provide a realistic magnitude of shifts in $\mathrm{P}$ release and $\mathrm{P}$ availability by fire events of different intensity for widely abundant ecosystem conditions. Taking the importance of $\mathrm{P}$ for ecosystem processes into account, these results are highly relevant, because fires for fuel reduction are a common application, and for temperate and boreal ecosystems even moderate climate change scenarios predict an increasing appearance of fires in these regions.

Key words: biogeochemistry; black ash; ecosystem processes; fire impact; fuel reduction; incineration; nutrients; phosphorus availability; plant nutrition; Tharandt Forest, Germany; topsoil.
\end{abstract}

\section{INTRODUCTION}

In the course of global climate change, terrestrial ecosystems are subjected to increasingly longer drought intervals (Nepstad et al. 1999, Richard et al. 2001, Breshears et al. 2005, Xiao et al. 2009). Drought, in turn, enhances the possibility of fire in these ecosystems (Xiao and Zhuang 2007). Simulations show that global climate change could lead to a strong increase of fire probabilities in some regions, but decrease in others (Krawchuk et al. 2009). Consequently, the relevance of fire as a driving force for the structure and functioning of terrestrial ecosystems in many regions may increase due to global change (Kelly et al. 2013). Fires are both natural (independent from humans) and human-set (Bowman et al. 2011), and occur seasonally, depending on latitude and longitude (Carmona-Moreno et al.

Manuscript received 4 July 2014; revised 5 November 2014; accepted 18 November 2014. Corresponding Editor: R. A. Dahlgren.

${ }^{5}$ Present address: Environmental Geochemistry, Bayreuth Center for Ecology and Environmental Research (BayCEER), University of Bayreuth, 95440 Bayreuth, Germany.

E-mail: Joerg.Schaller@uni-bayreuth.de
2005). Most fires are soil surface fires, impacting not only vegetation but also surficial organic soil layers (Gonzalez-Perez et al. 2004). Different fire intensities (differing in temperature and duration) occur, resulting in a transformation of the initial organic matter to either "black carbon" (BC, formed at $\sim 350^{\circ} \mathrm{C}$ by smoldering fire) or ash (formed at $\sim 550^{\circ} \mathrm{C}$, full oxidation) (Gonzalez-Perez et al. 2004), with possible contrasting effects on nutrient cycling within these systems. The transformation of organic matter to black carbon and ash also depends on soil moisture and organic layer thickness, with a strong decrease of oxygen with increasing organic layer thickness and soil moisture resulting in smoldering fires with a duration of several hours (Gonzalez-Perez et al. 2004, Bento-Goncalves et al. 2012). With this transformation from organic matter to $\mathrm{BC}$ or ash, the chemical properties may change, resulting not only in changed nutrient content (e.g., carbon and nitrogen can degas due to burning) (Page et al. 2002, Gonzalez-Perez et al. 2004), but also in altered nutrient availability (e.g., mineralization of organic matter of different intrinsic biodegradability, changes in sorption capacity) (Pereira et al. 2012). 
The relevance for phosphorus $(\mathrm{P})$ in this context is clear, because of its significant impact on biomass production in terrestrial and aquatic ecosystems (Tilman et al. 1986, Elser et al. 2007). The availability of inorganic $\mathrm{P}$ in terrestrial ecosystems depends in part on bedrock, state of soil formation, $\mathrm{pH}$, and P-binding soil materials (Marschner 2003). Organic layers of soils are important in this context, because they store high amounts of P. During vegetation development, large amounts of mineral $\mathrm{P}$ are relocated from mineral soil to the soil surface via plant litter and are particularly immobilized as organic P (Walker and Syers 1976, Vitousek et al. 2010). Large quantities of plant roots are abundant in close vicinity to these substrates, producing extracellular phosphatases to hydrolyze or mobilize the organic bound $\mathrm{P}$ sources. The organic layer is also important for the export of $\mathrm{P}$ from forest to aquatic systems (Nixon et al. 1996), where P is important for carbon turnover in phytoplankton (Tilman et al. 1986). However, the impact of fire in relation to these welldocumented processes is not entirely clear.

During burning of organic matter, $\mathrm{P}$ availability increases significantly (Ewel et al. 1981). The highest $\mathrm{P}$ availability was found for BC compared to ash, although differences were limited (Ngoc Nguyen et al. 2014). Yet, the possible P-binding components in ash responsible for this reduction of $\mathrm{P}$ availability are not known.

Considering the effects of fire on terrestrial and neighboring aquatic ecosystems via impact on $P$ availability, it is important to assess the impact of fire on terrestrial $\mathrm{P}$ availability for different fire treatments (resulting in BC or ash) and different soil organic layer types (from different ecosystems). Most fire studies relate nutrient content to the soil mass after burning, typically being field studies that simply measured the $\mathrm{P}$ availability in the remaining material (Humphreys and Lambert 1965, Ewel et al. 1981, Turrion et al. 2010, Pereira et al. 2012, Ngoc Nguyen et al. 2014), not relative to the initial soil mass prior to burning, which can lead to overestimations of $\mathrm{P}$ availability and may lead to incorrect conclusions. In order to overcome this lack of knowledge and some existing inconsistencies, we estimated the impact of fire on $\mathrm{P}$ availability related to initial soil mass in three different types of organic soil layers (raw humus from spruce, humus from beech, and peat) in a laboratory experiment with two fire regimes (to obtain BC and ash). These three types of organic soil layers are common and highly important organic layer types of boreal forests (Berg and McClaugherty 2008). Our hypothesis is that both fire treatments will result in a strong increase of $\mathrm{P}$ availability. Further, we hypothesize that the origin of the burned material determines the magnitude of $\mathrm{P}$ mobilization.

\section{Material And Methods}

\section{Soil organic matter}

Material from the soil organic layer (litter layer, uppermost $2 \mathrm{~cm}$ ) of two different tree populations on
Dystric Cambisols, Norway spruce (Picea abies) and European beech (Fagus sylvatica), each sampling soil organic matter from different sites within the whole forest $(n=10)$, was collected in Tharandt Forest near Dresden, Germany. In addition, commercial white peat (Sphagnum spp.) of different sources $(n=10)$ was used. These three litter types were chosen because they represent litter detritus from the most relevant boreal ecosystems (coniferous forests, broadleaf forest, and peat bogs) (Berg and McClaugherty 2008). Prior to analysis and burning, litter was sieved using a 2-mm nylon sieve for homogenization and was subsequently dried at $40^{\circ} \mathrm{C}$ until constant mass. The carbon content was $47 \% \pm 1.5 \%$ for humus from spruce, $35 \% \pm 3.1 \%$ for humus from beech, and $48 \% \pm 2.8 \%$ for peat. Nitrogen content was $2.0 \% \pm 0.1 \%$ for humus from spruce, $1.8 \% \pm 0.2 \%$ for humus from beech, and $1.1 \% \pm$ $0.1 \%$ for peat. Total organic layer thickness was $8 \pm$ $3 \mathrm{~cm}$ for raw humus from spruce and $4 \pm 2 \mathrm{~cm}$ for humus from beech; typical thickness of peat ranges from a few centimeters to more than a meter.

\section{Experimental setup}

Soil fires vary in terms of temperature within the uppermost soil layer, where the maximum observed temperatures are up to $630^{\circ} \mathrm{C}$ (Schimmel and Granstrom 1996, Romanya et al. 2001). However, the standard temperature for the determination of loss on ignition is $550^{\circ} \mathrm{C}$ (DIN-EN-12879:2000 2001), which is also a commonly measured temperature during soil fire (Romanya et al. 2001). However, most fire temperatures in the field setting are lower, resulting in incomplete oxidation of organic material and subsequent formation of $\mathrm{BC}$ (temperature range $300-400^{\circ} \mathrm{C}$ ). Fire duration also varies from minutes to hours, depending on oxygen availability; smoldering fires having durations of many hours are highly important for black carbon formation, with thick organic layers and ash formation being the end-product of incineration (complete oxidation) (Gonzalez-Perez et al. 2004, Bento-Goncalves et al. 2012). Consequently, we chose experimental conditions simulating fire conditions and duration resulting in $\mathrm{BC}$ treatment $\left(350^{\circ} \mathrm{C}\right)$, ash treatment $\left(\mathrm{Ash}, 550^{\circ} \mathrm{C}\right)$, and no heating for the control treatment $(\mathrm{C})$. The heat experiment was conducted until a constant mass was achieved (2-6 h) using a muffle furnace, with slow oxygen supply rates, which is comparable to smoldering wildfires (Flinn and Wein 1977). We burned and weighed the sample until the mass was constant. Because the experiment was conducted until constant mass was achieved, a maximal oxidation of the organic material at the specific temperature can be assumed to result in $\mathrm{BC}$ and ash characteristics comparable to those of natural fires.

\section{$P$ measurements}

To determine the available phosphorus (P) fraction (indicated as $\mathrm{Pi}$ ), the Bray-P and Olsen methods were 
applied. The Bray-P method was applied for samples with $\mathrm{pH}<7$ (controls) to remove easily acid-soluble $\mathrm{P}$ forms. For the BC samples, as well as the ash samples $(\mathrm{pH}>7)$, the Olsen-P method was applied. Briefly, for the Bray method, $2.5 \mathrm{~g}$ dry matter was extracted with $50 \mathrm{~mL}$ of a solution containing $0.03 \mathrm{~mol} / \mathrm{L} \mathrm{NH} \mathrm{NH}_{4} \mathrm{~F}$ and $0.025 \mathrm{~mol} / \mathrm{L} \mathrm{HCl}$ (Bray and Kurtz 1945). Samples were soaked for $30 \mathrm{~min}$, followed by shaking at $180 \mathrm{rpm}$ for 10 minutes, and were subsequently filtered (low-phosphate filter, grade 131, Munktell, Germany). The method according to Olsen et al. (1954) was applied to remove dissolved and adsorbed $\mathrm{P}$ from calcium carbonate (and Fe-oxide surfaces). One g dry matter was extracted with $50 \mathrm{~mL}$ of a solution containing $0.5 \mathrm{~mol} /$ $\mathrm{L} \mathrm{NaHCO}_{3}$ (Olsen et al. 1954). Samples were soaked for $30 \mathrm{~min}$, followed by shaking at $180 \mathrm{rpm}$ for 30 minutes, and were subsequently filtered (low-phosphate filter, grade 131, Munktell, Germany). After filtration, $40 \mathrm{~mL}$ of the extract was neutralized by addition of $5 \mathrm{~mL}$ of $5 \mathrm{~mol} / \mathrm{L} \mathrm{HCl}$ and subsequently sonicated for $5 \mathrm{~min}(50 \mathrm{~J} /$ s) in order to remove $\mathrm{CO}_{2}$ from the extract. A comparison of both methods clearly demonstrated that for BC and Ash treatments, the Bray-P method did not produce reliable results and had a low extraction efficiency (due to the high $\mathrm{pH}$ of the burned material, the assay $\mathrm{pH}$ was not constantly $\mathrm{pH}<3$ during soaking). Molybdate-reactive inorganic $\mathrm{P}$ content (Pi) in the extracts (Bray-P as well as Olsen-P) was measured photometrically with a continuous-flow autoanalyzer at 880 nm (Skalar Analytik GmbH, Breda, The Netherlands). The total (organic and inorganic) $\mathrm{P}$ content $(\mathrm{Pt})$ of the extracts (Bray-P as well as Olsen-P) was determined by SPECTRO CIROS VISION ICP-OES (inductively coupled plasma optical emission spectrometer; Acme Analytical Laboratories, Vancouver, British Columbia, Canada). The total phosphorus content (TP) (acid digestion using aqua regia) of the three different soil organic matter types was analyzed by ICP-OES (DIN-EN-13346 2001).

Previous published data for fire effects on element availability (field data as well as laboratory experiments) are mostly related to the soil mass after burning (Turrion et al. 2010, Pereira et al. 2012, Ngoc Nguyen et al. 2014). However, element availability should be related to the initial mass prior to burning, because only this relation allows a correct and realistic interpretation of the fire effect on element availability. Here we present $P$ availability data in relation to mass after burning and to the initial mass prior to burning.

\section{Thermoanalysis and $X$-ray diffraction}

Thermoanalysis and X-ray diffraction were performed on ash samples to characterize possible P-binding constituents. Thermoanalyses of the ashes were carried out by a simultaneous thermal analyzer, STA 409c/CD (Netzsch, Selb, Germany). Samples of about $50 \mathrm{mg}$ were heated to $1000^{\circ} \mathrm{C}$ with a heating rate of $10 \mathrm{~K} / \mathrm{min}$ under a constant nitrogen flow of $75 \mathrm{~mL} / \mathrm{min}$ using $\mathrm{Al}_{2} \mathrm{O}_{3}$ as a reference material. X-ray diffraction was performed using a Diffractometer FPM (Freiberger Präzesionsmechanik, Freiberg, Germany) RD7 ( $\mathrm{CuK}_{\alpha}$ radiation; Ni monochromator; angle range of $2-80^{\circ} 2 \theta$, step scan $8.0 \mathrm{~s}$, step sizes $0.02^{\circ}$ ) to characterize the ashes from the $550^{\circ} \mathrm{C}$ fire treatment. Zinc oxide was added to the ash as an internal standard with a final target concentration of $10-20 \%$. We used the BGNM program to perform Rietveld refinement. ${ }^{6}$

\section{Statistics}

ANOVA and the Scheffé post hoc test were used for comparison of the data using SPSS version 21.0 (IBM, Armonk, New York, USA); all $P$ values are from ANOVA unless otherwise specified.

\section{RESUlts}

\section{Mass loss by fire treatments}

A significant mass loss for all fire treatments and different litter types was found ( $P<0.001$; see Fig. 1). During the $350^{\circ} \mathrm{C}$ burning (resulting in BC), the mass loss was $64 \% \pm 3 \%$ (mean $\pm \mathrm{SD}$ ) for raw humus from spruce, $54 \% \pm 4 \%$ for humus of beech, and $70 \% \pm 3 \%$ for peat. At $550^{\circ} \mathrm{C}$ (resulting in ash) mass loss was $89 \%$ $\pm 0.4 \%$ for humus from spruce, $70 \% \pm 1.4 \%$ for humus from beech, and $93 \% \pm 0.5 \%$ for peat.

The total $\mathrm{P}$ (total $\mathrm{P}$, acid-digested using aqua regia) content of the initial organic material was differed significantly between all litter types $(P<0.001)$. Spruce litter had $828 \mathrm{mg} \mathrm{P} / \mathrm{kg} \mathrm{DM}$ (dry matter), beech litter had $5100 \mathrm{mg} \mathrm{P} / \mathrm{kg} \mathrm{DM}$, and peat $265 \mathrm{mg} \mathrm{P} / \mathrm{kg} \mathrm{DM}$ (Fig. 2).

The $\mathrm{pH}$ values for the initial organic material were significantly different $(P<0.01)$. Spruce litter had a $\mathrm{pH}$ of $3.9 \pm 0.1$ (mean $\pm \mathrm{SD})$, beech litter $\mathrm{pH}$ was $3.3 \pm 0.1$, and the peat $\mathrm{pH}$ was $3.1 \pm 0.1$. During combustion at $350^{\circ} \mathrm{C}$ (resulting in $\left.\mathrm{BC}\right), \mathrm{pH}$ increased significantly $(P<$ 0.001 ) to $8.5 \pm 0.3$ (spruce), $7.7 \pm 0.3$ (beech), and $9.6 \pm$ 0.2 (peat). Combustion at $550^{\circ} \mathrm{C}$ (resulting in ash) increased the $\mathrm{pH}(P<0.001)$ to $10 \pm 0.2$ (spruce), $9.4 \pm$ 0.2 (beech), and $11.2 \pm 0.1$ (peat). The $\mathrm{pH}$ values were significantly different for $\mathrm{BC}$ and ash from the different litter types $(P<0.001)$.

\section{Fire effects on $P$ availability}

Significant differences (ANOVA, $P<0.001$; Scheffé post hoc test) between the fire treatments and the litter types were found for Pi (inorganic $\mathrm{P}$ within the extracts) related to initial mass prior to burning (Fig. 3). Inorganic $\mathrm{P}$ was lower for ash than for $\mathrm{BC}$, but still higher than controls.

Relative to mass after burning, we found significant differences between all fire treatments and litter types $(P$ $<0.001$; see Appendix: Fig. A1). The Scheffé post hoc test revealed significant differences $(P<0.001)$ for all

${ }^{6}$ http://programming.ccp14.ac.uk/solution/rietveld_software/ index.html 


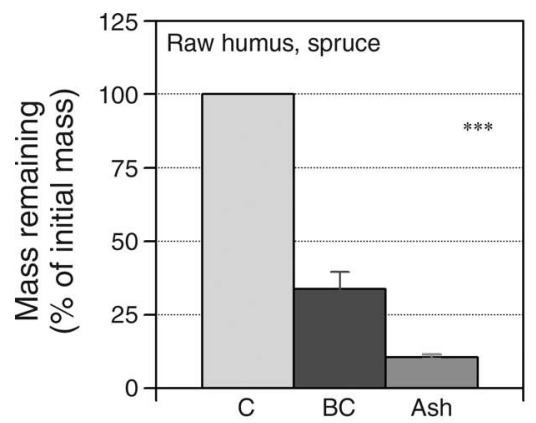

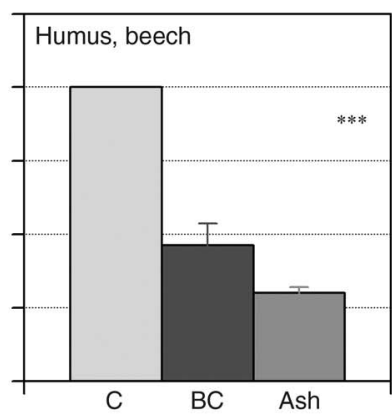

Fire treatment

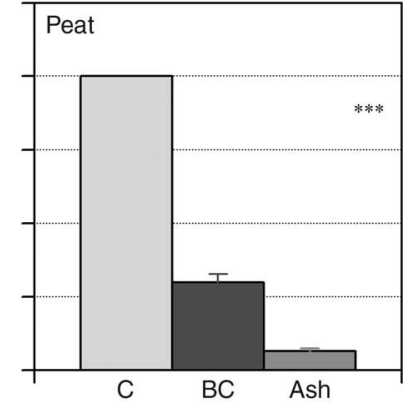

FIG. 1. Amount of mass remaining (mean $+\mathrm{SE})$ of three types of organic matter after different fire treatments $(\mathrm{C}$, control; BC, black carbon; Ash). Different fire intensities (differing in temperature and duration) transform the initial organic matter to either black carbon (formed at $\sim 350^{\circ} \mathrm{C}$ by smoldering fire) or ash (formed at $\sim 550^{\circ} \mathrm{C}$, full oxidation). We chose material from the soil organic litter layer (uppermost $2 \mathrm{~cm}$ ) of Norway spruce (Picea abies) and European beech (Fagus sylvatica), collected in Tharandt Forest near Dresden, Germany, and commercial white peat (Sphagnum spp.) to represent litter detritus from coniferous forests (raw or mor humus), broadleaf forests (mull humus), and peat bogs, respectively. There were significant differences $(* * * P<0.001)$ between all treatments.

fire treatments, except for comparison of $\mathrm{BC}$ and ash. The Pi values relative to mass after burning (or without burning for control) were lowest for the control treatment. Inorganic $\mathrm{P}$ from the $\mathrm{BC}$ treatment was significantly higher than $\mathrm{Pi}$ of the control treatment for all litter types. Likewise, $\mathrm{Pi}$ of the ash was significantly higher compared to the control treatment for all litter types.

For Pt (total $\mathrm{P}$ within the extracts) relative to initial mass prior to burning we found significant differences (ANOVA, $P<0.001$; Scheffé post hoc test) between all fire treatments and litter types (Fig. 3). Total extractable $\mathrm{P}$ related to mass prior to burning for $\mathrm{BC}$ was highest. In addition, $\mathrm{Pt}$ of ash was higher than that of the control treatment, except for peat.

Relative to mass after burning (Appendix: Fig. A1) significant differences (ANOVA, $P<0.001$ ) between the fire treatments and the litter types were found. The Scheffé post hoc test revealed significant differences $(P$ $<0.001)$ for all treatments, except for comparison of BC and ash (not significant). Pt values relative to mass after burning (or without burning for control) were always lowest for the control; total extractable $\mathrm{P}$ of the $\mathrm{BC}$ treatment was significantly higher than that of the control treatment. In addition, $\mathrm{Pt}$ of ash was significantly higher than that of the $\mathrm{BC}$ treatment.

Because values of extractable $\mathrm{Pi}$ and $\mathrm{Pt}$ were of the same order of magnitude ( $\mathrm{Pi}$ is $\sim 90 \%$ of $\mathrm{Pt}$ ), we used values of inorganic $\mathrm{P}$ for further calculations. Compared to the control samples, inorganic $\mathrm{P}$ (relative to mass prior to burning) significantly increased $(P<0.001)$ by burning to $\mathrm{BC}$ by 10 -fold (spruce), $\sim 10$-fold (beech), and $\sim 17$-fold (peat) (Fig. 4 ), whereas heating to $550^{\circ} \mathrm{C}$ (Ash) significantly reduced inorganic $\mathrm{P}(P<0.001)$ compared to $\mathrm{BC}$, but still increased inorganic $\mathrm{P}$ related to control treatments by fourfold (spruce), sevenfold (beech), and twofold (peat).
The Pi values relative to the total $\mathrm{P}$ concentration of the bulk organic material (TP, acid-digested using aqua regia) of control samples prior to burning increased significantly $(P<0.001)$ by burning the controls to $\mathrm{BC}$ (Fig. 4). Further burning at $550^{\circ} \mathrm{C}$ (Ash) significantly reduced the extractable $\mathrm{Pi}$ proportion $(P<0.001)$. This means an increase in the proportion of $\mathrm{Pi}$ to TP by burning to $\mathrm{BC}$ of 10 - to 16 -fold and an increase from control to Ash of 2- to 7.5-fold. Certainly, we found high differences between the $\mathrm{Pi} / \mathrm{Pt}$ values of the different extraction methods (Bray vs. Olsen) for the BC and Ash samples; the $\mathrm{pH}$ of $\mathrm{BC}$ and the ashes was too high for the Bray method (compare Fig. 3 with Appendix: Figs. A2-A5).

\section{$X$-ray diffraction and thermoanalysis}

$\mathrm{X}$-ray diffraction pattern as well as thermograms of the ash samples revealed large differences between the types of organic matter (spruce, beech, and peat)

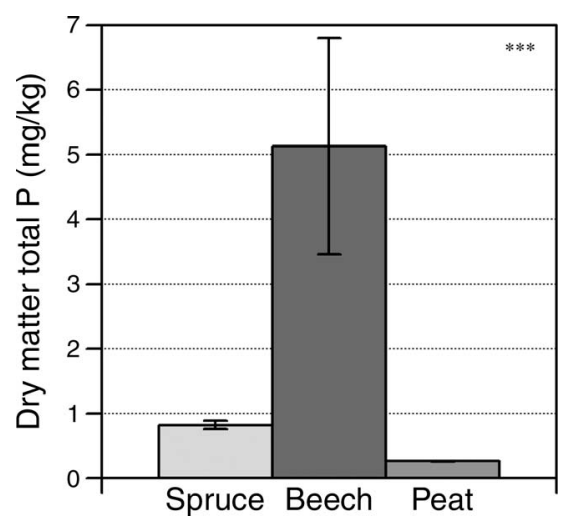

Fig. 2. Total $\mathrm{P}$ content (TP; mean $\pm \mathrm{SE}$ ) after digestion in aqua regia of the different types of organic matter used in the experiments. There were significant differences $(* * * P<0.001)$ between all organic matter types. 

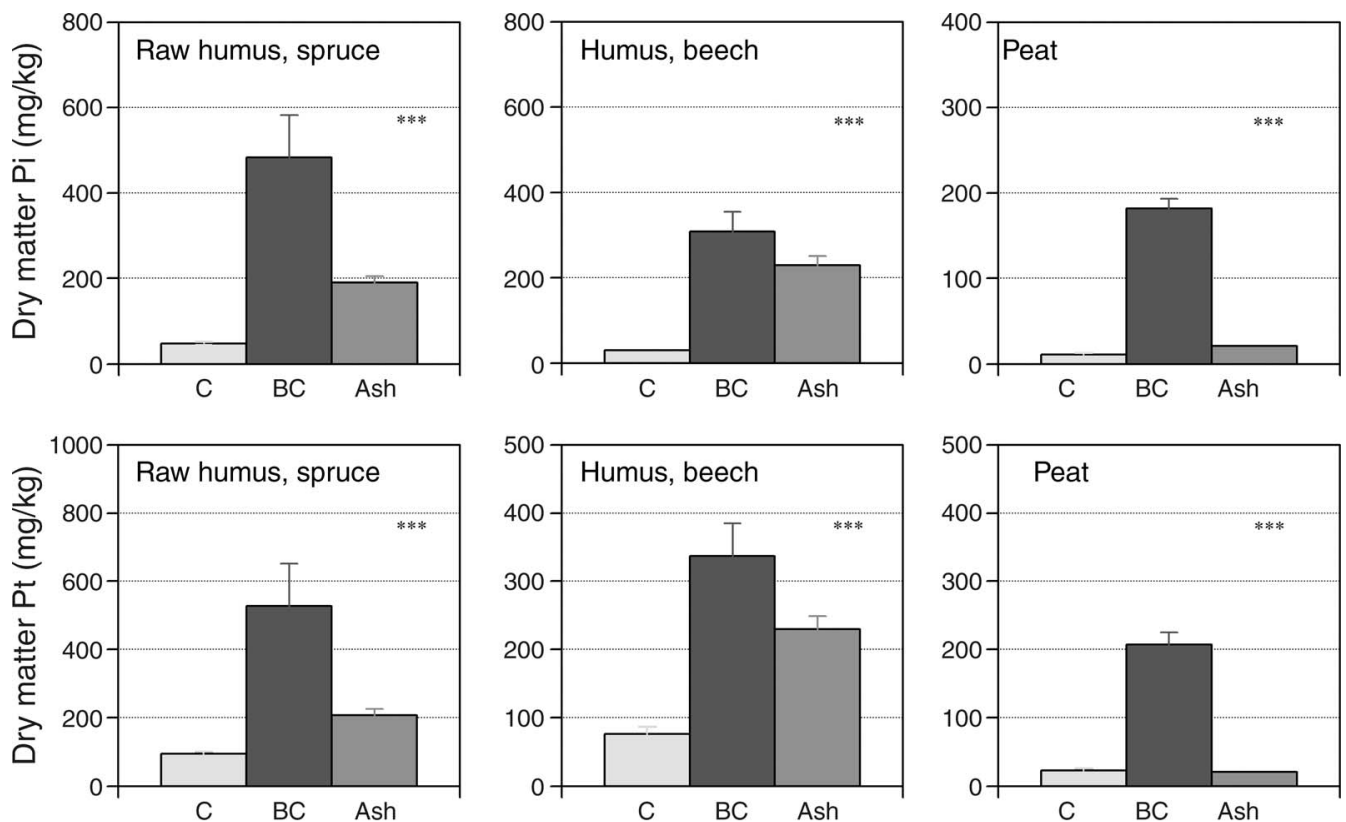

Fire treatment

FIG. 3. Extractable inorganic phosphorus (Pi) and extractable total phosphorus (Pt, or Olsen-Pt) from the different types of organic matter after different fire treatments $\left(\mathrm{C}\right.$, control; $\mathrm{BC}, 350^{\circ} \mathrm{C}$; Ash, $\left.550^{\circ} \mathrm{C}\right)$ related to initial mass prior to burning; values are mean + SE. For the control, Pi and Pt were analyzed after Bray and Kurtz (1945); Pi and Pt of black carbon and ash were analyzed after Olsen et al. (1954) in view of substrate $\mathrm{pH}$. There were significant differences $(* * * P<0.001)$ between all treatments.

(Appendix: Table A1). The largest difference was found for the calcite content of the different ashes. By far, the lowest calcite content was found for ash from beech (1$2 \%$ ), with much higher values for ash from spruce (7$9 \%$ ) and peat $(15.5-19.5 \%)$. We also found large differences for crystalline $\mathrm{SiO}_{2}$ content, as the litter types contained soil particles (spruce ash $12 \%$, beech ash 59-63\%, and peat ash 40\%). Furthermore, the amorphous share (e.g., amorphous $\mathrm{SiO}_{2}$ ) of the ashes was different (spruce $74-78 \%$, beech $35-40 \%$, and peat $40-$
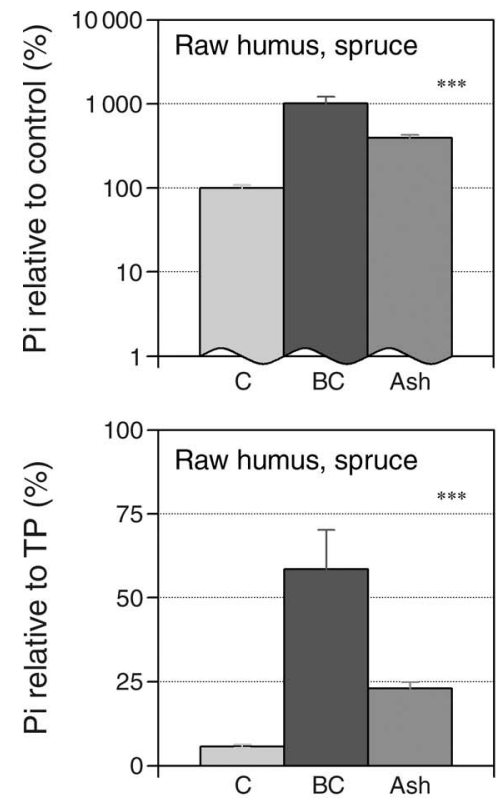
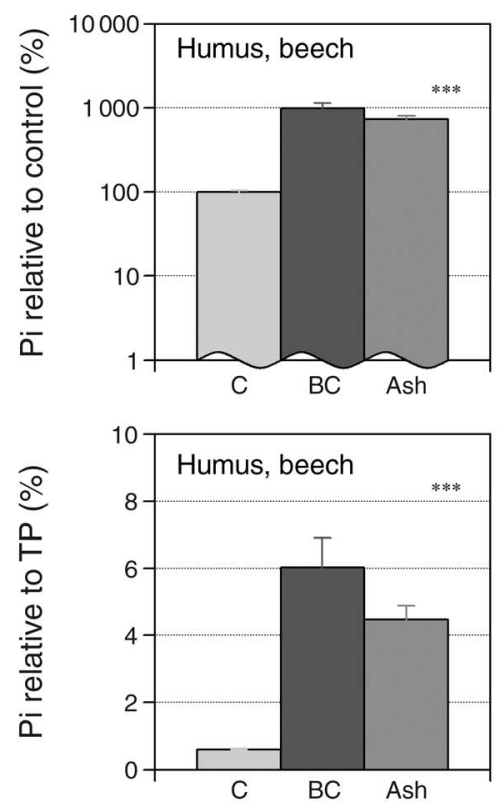

Fire treatment
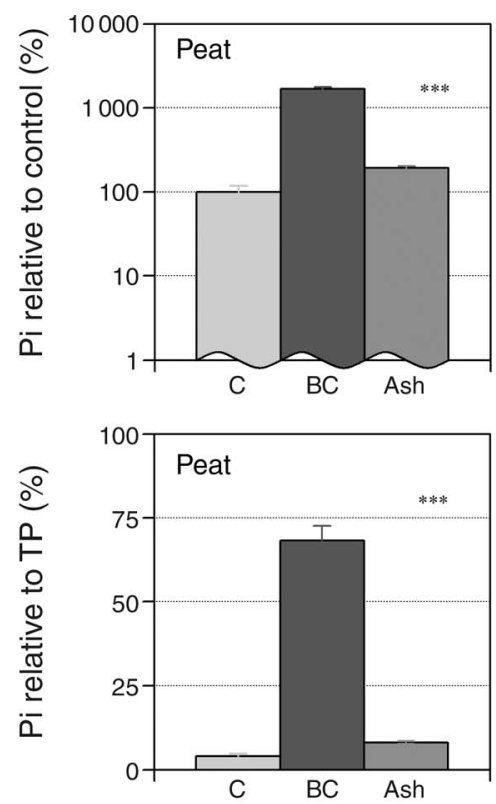

FIG. 4. Percentage availability of Pi (mean + SE) related to values of the control treatment and to total (bulk) phosphorus (TP) of initial soil samples. There were significant differences $(* * * P<0.001)$ between all treatments. 
$45 \%$ ). The thermograms (different heating steps) revealed low amounts of (1) adsorptive bound water, (2) silica-bound water, (3) organic and silica bound water, (4) calcite, and (5) amorphous silica (Appendix: Table A1). Thermograms of the control samples as well as the BC samples showed no differences between the different types of organic matter (data not shown).

\section{DisCUSSION}

Our results showed a clear increase of $\mathrm{P}$ availability by fire, confirming most other findings in this research field (Humphreys and Lambert 1965, Pereira et al. 2012, Ngoc Nguyen et al. 2014). We also demonstrated that the $\mathrm{P}$ availability in black carbon is similar to that in ash for the forest organic soil layer relative to mass after burning. However, our manuscript is the first to relate the $\mathrm{P}$ availability to initial mass of the organic matter prior to burning. Calculating $\mathrm{P}$ relative to the remaining mass after burning, as is commonly done, overestimates $\mathrm{P}$ availability by up to 14 -fold. To avoid misleading interpretations of the absolute mobilization of $\mathrm{P}$ by fire, care should be taken when assessing available $\mathrm{P}$ from data related to mass after burning as is often reported (Humphreys and Lambert 1965, Ewel et al. 1981, Pereira et al. 2012, Ngoc Nguyen et al. 2014). For determination of $\mathrm{P}$ availability, both extraction methods (Bray-P and Olsen-P) were reported to be sensitive indicators for soil P availability for plants (Fixen and Grove 1990) and soil microorganisms (Demetz and Insam 1999). The $P$ availability was strongly enhanced during $350^{\circ} \mathrm{C}$ burning to $\mathrm{BC}$ for all litter types. During burning of organic material to $\mathrm{BC}$, the unavailable $\mathrm{P}$ is converted to available P (Certini 2005) and may be adsorbed to the anion exchange sites of the $\mathrm{BC}$ (organic phases with highly condensed carbon compounds, consisting of low amounts of hydrogen and high amounts of carbon) (Liang et al. 2006, Morales et al. 2013).

We found an increase of available inorganic $\mathrm{P}$ for the ash treatment; however, the increase was an order of magnitude lower than for the $\mathrm{BC}$ treatment (Fig. 3). The results obtained from X-ray diffraction as well as from thermoanalysis (Appendix: Table A1) suggest that the reduction of $\mathrm{P}$ availability from $\mathrm{BC}$ to ash was related to the calcite content of the ash. Decreasing $\mathrm{P}$ availability with increasing calcite content of ash was observed previously (Gonsiorczyk et al. 1998). Because the content and the absolute flux of $\mathrm{Ca}$ via litterfall are related to plant traits (Kattge et al. 2011), the life strategies of the respective plant species probably exert important effects on $\mathrm{P}$ availability after fire. However, the calcium impact on $\mathrm{P}$ availability may decrease over time due to acidification and dissolution of the calcite. Relating available $\mathrm{P}$ ( $\mathrm{Pi}$ of the extracts) to the total $\mathrm{P}$ content (TP, acid-digested using aqua regia) of the organic material showed that the shift of $\mathrm{P}$ availability is independent of total $\mathrm{P}$ of the initial organic material. This was indicated by the beech samples, showing the lowest relative $\mathrm{P}$ availability despite a more than sixfold
TABle 1. Average $\mathrm{P}$ stocks stored in different ecosystem components of comparable stands of beech (Fagus sylvatica) and Norway spruce (Picea abies), from the present study and literature from representative stands of the Tharandt Forest or comparable areas in NE Germany.

\begin{tabular}{|c|c|c|}
\hline Component & Fagus & Picea \\
\hline \multicolumn{3}{|l|}{ Soil layer, Oe and $\mathrm{Oa}$} \\
\hline Soil mass $(\mathrm{kg} / \mathrm{ha}) \dagger$ & 99.6 & 78.4 \\
\hline Total P (kg P/ha $) \ddagger$ & 507.96 & 64.92 \\
\hline \multicolumn{3}{|l|}{ Plant-available P (kg P/ha) } \\
\hline Control & 1.49 & 1.96 \\
\hline $\mathrm{BC}$ & 30.78 & 37.95 \\
\hline Ash & 22.81 & 14.97 \\
\hline Litterfall P $\left(\mathrm{kg} \mathrm{P} \cdot \mathrm{ha}^{-1} \cdot \mathrm{yr}^{-1}\right) \S$ & $3.95-9.77$ & $1.54-2.71$ \\
\hline \multicolumn{3}{|l|}{ Tree biomass P, 120 -yr-old stand } \\
\hline Total $\mathrm{P}$, aboveground ( $\mathrm{kg} \mathrm{P} /$ ha) & $65.90 \S$ & $52.79 \S$ \\
\hline Total $\mathrm{P}$, harvested $(\mathrm{kg} \mathrm{P} / \mathrm{ha})$ & $97.80 \S$ & $42.69 \S$ \\
\hline $\mathrm{P}$ uptake by trees $\left(\mathrm{kg} \mathrm{P} \cdot \mathrm{ha}^{-1} \cdot \mathrm{yr}^{-1}\right)$ & $5.10-11.11 \S$ & $3.14-8.219$ \\
\hline
\end{tabular}

$\dagger$ Koch and Makeschin (2004) calculated oven-dry $\left(105^{\circ} \mathrm{C}\right)$ soil mass for each study site from six randomly arranged $10 x$ $10 \mathrm{~m}$ plots, each with a sample of the organic Oe and Oa layers composited from three subsamples taken in a $0.2 \times 0.2 \mathrm{~m}$ frame.

士 We calculated total P and plant-available Pi in organic soil layers by multiplying the dry mass of particular horizons (soil mass data from Koch and Makeschin 2004), by P concentrations from our three fire treatments (control, black carbon, and ash).

§ Litterfall data for Picea were from Dietrich (1963). Litterfall data for Fagus were compiled from Grunert (1964), who installed $101-\mathrm{m}^{2}$ litter traps per stand $(n=3)$ over a 5 -yr period ( $\mathrm{P}$ averaged over all seasons), and from Krauß and Heinsdorf (2008), who sampled 14 trees. All trees were harvested, tree biomass was determined for several subsections and components, and litter mass was determined by sampling green leaves. Based on these data, we developed allometric functions to estimate biomass of several components of Fagus as a function of tree dbh and tree height based on multiple linear regression analyses, and dependent on soil nutrient status. We calculated biomass stocks for a 120-yr-old Fagus stand and a comparable production potential class M28. Litterfall and annual $\mathrm{P}$ uptake represented a stand age range of 30-120 yr (M28). We also considered Fagus P uptake data from the literature survey of Jacobsen et al. (2003).

- For Picea abies, we calculated biomass, $\mathrm{P}$ in biomass, and $\mathrm{P}$ uptake for a 120-year-old stand (class M28) using biomass data based on growth models (production potential) compiled by Wenk et al. (1985) for the study region and $\mathrm{P}$ data from Jacobsen et al. (2003). We corrected biomass estimates assuming 26\% tree crown biomass (Jacobsen et al. 2003) and applied a factor for Picea timber density of of $377.1 \mathrm{~kg} / \mathrm{m}^{3}$. Average $\mathrm{P}$ concentration of aboveground biomass was set as $0.014 \mathrm{mg} \mathrm{P} / \mathrm{g}$ (Nebe and Herrmann 1987), a weighted-average $P$ content proportional to the contribution of all tree components (stem, bark, crowns, leaves) to spruce aboveground biomass representative for the study area.

higher initial total $\mathrm{P}$ content. This may be explained by the immobilization of phosphate by calcite minerals, as suggested by the low mass loss of beech material during burning.

Because many terrestrial ecosystems (especially forests) burn regularly (Goldammer 1993, Kelly et al. 2013), the impact of fire on $P$ availability is of general ecological significance. Altogether, our findings suggest a strong quantitative impact of fire on $\mathrm{P}$ availability within the respective ecosystems. Specifically, calculating the available $\mathrm{P}$ stocks in $\mathrm{kg} / \mathrm{ha}$ (Table 1) reveals that 


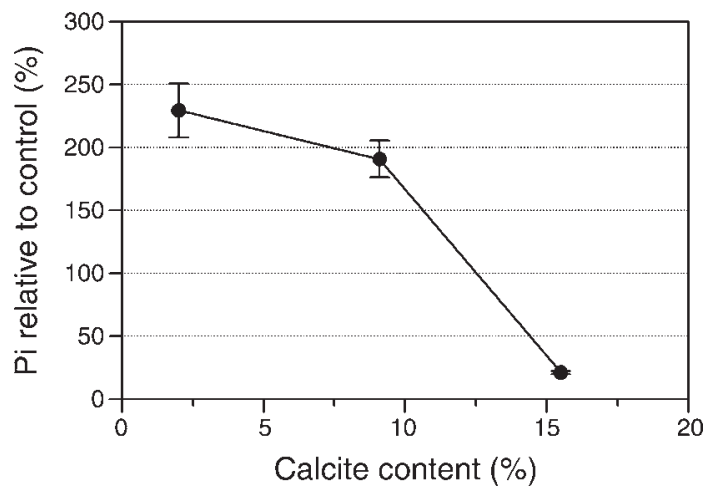

FIG. 5. Relationship between ash calcite content and percentage $\mathrm{Pi}$ (mean $\pm \mathrm{SE}$ ) relative to the control, for the ash treatment only.

transformation of unavailable to available $\mathrm{P}$ by fire is on the same order of magnitude as the total $\mathrm{P}$ bound by aboveground biomass in spruce and beech ecosystems. The $\mathrm{P}$ release by fire exceeds that of weathering $(0.005-$ $3.0 \mathrm{~kg} \mathrm{P} \cdot \mathrm{ha}^{-1} \cdot \mathrm{yr}^{-1}$ ) from parent material (Binkley and Fisher 2012) and the mineralization of organic P (between 2.6 and $25 \mathrm{~kg} \mathrm{P} \cdot \mathrm{ha}^{-1} \cdot \mathrm{yr}^{-1}$ ) (Walbridge 1991, Saggar et al. 1998). Furthermore, transformation of unavailable to available $\mathrm{P}$ by burning is much higher than the annual cycling of $\mathrm{P}$ via litterfall and annual $\mathrm{P}$ uptake by forest biomass for the respective tree species (Table 1 and literature cited therein). With increasing $\mathrm{P}$ availability, the export of $\mathrm{P}$ from the soils to aquatic ecosystems potentially rises (Kreutzweiser et al. 2008) due to insufficient $\mathrm{P}$ uptake and subsequent reduced sequestration by plants (annual P uptake is lower compared to $\mathrm{P}$ mobilization by fire). Furthermore, ecosystem $\mathrm{P}$ stocks after fire may be reduced due to $\mathrm{P}$ loss by volatilization as suggested earlier (Kauffman et al. 1993), or rather losses of particulate-bound $\mathrm{P}$ via convection in fire-generated winds (Binkley and Fisher 2012). Consequently, ecosystem $P$ stocks may be reduced at longer time scales due to enhanced leaching (until weathering recovers the former $\mathrm{P}$ availability), erosion, or losses of particulate-bound $\mathrm{P}$ via convection in fire-generated winds.

It is of high importance to relate the availability of $\mathrm{P}$ after burning to the initial litter mass prior to burning to avoid significant overestimation and, hence, incorrect interpretations and conclusions. We showed significant effects of fire on P availability of organic soil layers. The less available $\mathrm{P}$ of the initial organic matter was, to a substantial degree, mobilized as a fraction easily available for plants $(\mathrm{Pi})$. Fire temperature had a significant impact on $\mathrm{P}$ availability. The intermediate fire treatment $\left(\mathrm{BC}, 350^{\circ} \mathrm{C}\right)$ caused the highest amount of $P$ availability, whereas the more intensive fire treatment (incineration to ash at $550^{\circ} \mathrm{C}$ ) increased the $\mathrm{P}$ availability to a lower extent than did BC. Consequently, fire temperature must be considered in regard to fires for fuel reduction (Agee and Skinner 2005), because low temperature (smoldering fires) will strongly increase $\mathrm{P}$ availability and possible $\mathrm{P}$ export to adjacent ecosystems. Our data further suggest that the mobilization of $\mathrm{P}$ depends on the calcite content of the ash (Fig. 5), with calcite forming $\mathrm{P}$ forms of low solubility which, in turn, reduces easily available P. Altogether, the quantitative effect of fire on $\mathrm{P}$ availability is equally important as the annual $\mathrm{P}$ uptake by biomass and more important than mineral weathering for the respective forest ecosystems. As suggested by the percentage increase of $P$ availability by fire, the origin of organic material (i.e., plant species) is an important determinant for the release of easily available $\mathrm{P}$ by burning. This importance is not associated with the initial $\mathrm{P}$ content but is probably related to the content of ions forming stable $\mathrm{P}$ forms (e.g., calcium-phosphates) not readily available to plants. Altogether, the impact of wildfires and fire temperature and its impact on $\mathrm{P}$ availability in topsoils must be considered in regard to the predicted change in fire regimes in the course of global climate change, with a potential strong increase of fire probabilities in some regions, but decreased probabilities in others (Krawchuk et al. 2009).

\section{ACKNOWLEDGMENTS}

The authors are grateful for Armin Schmidt and Gisela Ciesielski (both Institute of General Ecology, TU Dresden); Manuela Unger (Institute of Soils Science and Soil Protection, TU Dresden); Jana Schneider MFPA Leipzig GmbH for thermoanalysis; Udo Steiner (HTW-Dresden, faculty mechanical engineering/process engineering and chemical engineering) for X-ray diffraction; and Thomas Klinger and Arndt Weiske for ICP-OES measurements. Furthermore, we are grateful to Peter Vitousek (Stanford University, USA) and Wim Clymans (Department of Geology, Lund University, Sweden) for comments on early drafts of the manuscript. Eric Struyf and Dácil Unzue Belmonte would like to thank BELSPO for funding project SOGLO.

\section{Literature Cited}

Agee, J. K., and C. N. Skinner. 2005. Basic principles of forest fuel reduction treatments. Forest Ecology and Management 211:83-96.

Bento-Goncalves, A., A. Vieira, X. Ubeda, and D. Martin. 2012. Fire and soils: key concepts and recent advances. Geoderma 191:3-13.

Berg, B., and C. McClaugherty. 2008. Plant litter. SpringerVerlag, Berlin, Germany.

Binkley, D., and R. Fisher. 2012. Ecology and management of forest soils. John Wiley, New York, New York, USA.

Bowman, D., et al. 2011. The human dimension of fire regimes on Earth. Journal of Biogeography 38:2223-2236.

Bray, R. H., and L. T. Kurtz. 1945. Determination of total, organic, and available forms of phosphorus in soil. Soil Science 59:39-45.

Breshears, D. D., et al. 2005. Regional vegetation die-off in response to global-change-type drought. Proceedings of the National Academy of Sciences USA 102:15144-15148.

Carmona-Moreno, C., A. Belward, J. P. Malingreau, A. Hartley, M. Garcia-Alegre, M. Antonovskiy, V. Buchshtaber, and V. Pivovarov. 2005. Characterizing interannual variations in global fire calendar using data from Earthobserving satellites. Global Change Biology 11:1537-1555.

Certini, G. 2005. Effects of fire on properties of forest soils: a review. Oecologia 143:1-10. 
Demetz, M., and H. Insam. 1999. Phosphorus availability in a forest soil determined with a respiratory assay compared to chemical methods. Geoderma 89:259-271.

Dietrich, H. 1963. Untersuchungen zum Nährstoffkreislauf von Fichtenbeständen im Osterzgebirge. Archiv für Forstwesen 12:1116-1136.

DIN-EN-12879:2000. 2001. Bestimmung des Glühverlustes der Trockenmasse. Deutsches Institut für Normung e.V., Berlin, Germany.

DIN-EN-13346. 2001. Bestimmung von Spurenelementen und Phosphor, Extraktionsverfahren mit Königswasser. Deutsches Institut für Normung, Berlin, Germany.

Elser, J. J., M. E. S. Bracken, E. E. Cleland, D. S. Gruner, W. S. Harpole, H. Hillebrand, J. T. Ngai, E. W. Seabloom, J. B. Shurin, and J. E. Smith. 2007. Global analysis of nitrogen and phosphorus limitation of primary producers in freshwater, marine and terrestrial ecosystems. Ecology Letters 10: $1135-1142$.

Ewel, J., C. Berish, B. Brown, N. Price, and J. Raich. 1981. Slash and burn impacts on a Costa Rican wet forest site. Ecology 62:816-829.

Fixen, P. E., and J. H. Grove. 1990. Testing soils for phosphorus. Pages 141-180 in R. L. Westerman, editor. Soil testing and plant analysis. SSSA Book Series, Madison, Wisconsin, USA.

Flinn, M. A., and R. W. Wein. 1977. Depth of underground plant organs and theoretical survival during fire. Canadian Journal of Botany 55:2550-2554.

Goldammer, J. 1993. Historical biogeography of fire: tropical and subtropical. Pages 297-314 in P. J. Crutzen, and J. G. Goldammer, editors. Fire in the environment: the ecological atmospheric, and climatic importance of vegetation fires. Wiley, New York, New York, USA.

Gonsiorczyk, T., P. Casper, and R. Koschel. 1998. Phosphorusbinding forms in the sediment of an oligotrophic and a eutrophic hardwater lake of the Baltic lake district (Germany). Water Science and Technology 37:51-58.

Gonzalez-Perez, J. A., F. J. Gonzalez-Vila, G. Almendros, and H. Knicker. 2004. The effect of fire on soil organic matter-a review. Environment International 30:855-870.

Grunert, F. 1964. Der biologische Stoffkreislauf in KiefernBuchen-Mischbeständen und Kiefernbeständen. Archives of Agronomy and Soil Science 8:435-452.

Humphreys, F., and M. Lambert. 1965. An examination of a forest site which has exhibited the ash-bed effect. Australian Journal of Soil Research 3:81-94.

Jacobsen, C., P. Rademacher, H. Meesenburg, and K. J. Meiwes. 2003. Gehalte chemischer Elemente in Baumkompartimenten Literaturstudie und Datensammlung im Auftrage des BMVEL. Berichte des Forschungszentrums Waldökosysteme der Universität Göttingen, Göttingen, Germany.

Kattge, J., S. Diaz, S. Lavorel, I. Prentice, P. Leadley, G. Bönisch, E. Garnier, M. Westoby, P. B. Reich, and I. Wright. 2011. TRY - a global database of plant traits. Global Change Biology 17:2905-2935.

Kauffman, J. B., R. L. Sanford, Jr., D. L. Cummings, I. Salcedo, and E. Sampaio. 1993. Biomass and nutrient dynamics associated with slash fires in Neotropical dry forests. Ecology 74:140-151.

Kelly, R., M. L. Chipman, P. E. Higuera, I. Stefanova, L. B. Brubaker, and F. S. Hu. 2013. Recent burning of boreal forests exceeds fire regime limits of the past 10,000 years. Proceedings of the National Academy of Sciences USA 110: 13055-13060.

Koch, J. A., and F. Makeschin. 2004. Carbon and nitrogen dynamics in topsoils along forest conversion sequences in the Ore Mountains and the Saxonian lowland, Germany. European Journal of Forest Research 123:189-201.
Krauß, H. H., and D. Heinsdorf. 2008. Herleitung von Trockenmassen und Nährstoffspeicherung in Buchenbeständen. Eberswalder Forstliche Schriftenreihe 38:1-71.

Krawchuk, M. A., M. A. Moritz, M.-A. Parisien, J. Van Dorn, and K. Hayhoe. 2009. Global pyrogeography: the current and future distribution of wildfire. PLoS ONE 4:e5102.

Kreutzweiser, D. P., P. W. Hazlett, and J. M. Gunn. 2008. Logging impacts on the biogeochemistry of boreal forest soils and nutrient export to aquatic systems: a review. Environmental Reviews 16:157-179.

Liang, B., et al. 2006. Black carbon increases cation exchange capacity in soils. Soil Science Society of America Journal 70: $1719-1730$.

Marschner, H. 2003. Mineral nutrition of higher plants. Academic Press, London, UK.

Morales, M. M., N. Comerford, I. A. Guerrini, N. P. S. Falcao, and J. B. Reeves. 2013. Sorption and desorption of phosphate on biochar and biochar-soil mixtures. Soil Use and Management 29:306-314.

Nebe, W., and U. J. Herrmann. 1987. Das Ökologische Messfeld der Sektion Forstwirtschaft der TU Dresden. VI. Zur Verteilung der Nährelemente in der oberirdischen Dendromasse eines 100jährigen Fichtenbaumholzes. Wissenschaftliche Zeitschrift der Technischen Universität Dresden 36:235-241.

Nepstad, D. C., et al. 1999. Large-scale impoverishment of Amazonian forests by logging and fire. Nature 398:505-508.

Ngoc Nguyen, M., S. Dultz, and G. Guggenberger. 2014. Effects of pretreatment and solution chemistry on solubility of rice-straw phytoliths. Journal of Plant Nutrition and Soil Science 177:349-359.

Nixon, S. W., et al. 1996. The fate of nitrogen and phosphorus at the land sea margin of the North Atlantic Ocean. Biogeochemistry 35:141-180.

Olsen, S. R., C. V. Cole, F. S. Watanabe, and L. A. Dean. 1954. Estimation of available phosphorus in soils by extraction with sodium bicarbonate. USDA Circular 939. USDA, Washington, D.C., USA.

Page, S. E., F. Siegert, J. O. Rieley, H. D. V. Boehm, A. Jaya, and S. Limin. 2002. The amount of carbon released from peat and forest fires in Indonesia during 1997. Nature 420:61-65.

Pereira, P., X. Ubeda, and D. A. Martin. 2012. Fire severity effects on ash chemical composition and water-extractable elements. Geoderma 191:105-114.

Richard, Y., N. Fauchereau, I. Poccard, M. Rouault, and S. Trzaska. 2001. 20th century droughts in southern Africa: spatial and temporal variability, teleconnections with oceanic and atmospheric conditions. International Journal of Climatology 21:873-885.

Romanya, J., P. Casals, and V. R. Vallejo. 2001. Short-term effects of fire on soil nitrogen availability in Mediterranean grasslands and shrublands growing in old fields. Forest Ecology and Management 147:39-53.

Saggar, S., R. Parfitt, G. Salt, and M. Skinner. 1998. Carbon and phosphorus transformations during decomposition of pine forest floor with different phosphorus status. Biology and Fertility of Soils 27:197-204.

Schimmel, J., and A. Granstrom. 1996. Fire severity and vegetation response in the boreal Swedish forest. Ecology 77: $1436-1450$

Tilman, D., R. Kiesling, R. Sterner, S. S. Kilham, and F. A. Johnson. 1986. Green, bluegreen and diatom algaetaxonomic differences in competitive ability for phosphorus, silicon and nitrogen. Archiv für Hydrobiologie 106:473485 .

Turrion, M. B., F. Lafuente, M. J. Aroca, O. Lopez, R. Mulas, and C. Ruiperez. 2010. Characterization of soil phosphorus in a fire-affected forest Cambisol by chemical extractions and 
P-31-NMR spectroscopy analysis. Science of the Total Environment 408:3342-3348.

Vitousek, P. M., S. Porder, B. Z. Houlton, and O. A. Chadwick. 2010. Terrestrial phosphorus limitation: mechanisms, implications, and nitrogen-phosphorus interactions. Ecological Applications 20:5-15.

Walbridge, M. R. 1991. Phosphorus availability in acid organic soils of the lower North Carolina coastal plain. Ecology 72: 2083-2100.

Walker, T. W., and J. K. Syers. 1976. Fate of phosphorus during pedogenesis. Geoderma 15:1-19.
Wenk, G., K. Römisch, and D. Gerold. 1985. DDR-Fichtenertragstafel 1984. Agrarwissenschaftliche Gesellschaft der DDR. Technische Universität Dresden, Sektion Forstwissenschaften Tharandt, 64 S, Germany.

Xiao, J. F., and Q. L. Zhuang. 2007. Drought effects on large fire activity in Canadian and Alaskan forests. Environmental Research Letters 2:1-6.

Xiao, J. F., Q. L. Zhuang, E. Y. Liang, A. D. McGuire, A. Moody, D. W. Kicklighter, X. M. Shao, and J. M. Melillo. 2009. Twentieth-century droughts and their impacts on terrestrial carbon cycling in China. Earth Interactions 13:1-31.

\section{Supplemental Material}

\section{Ecological Archives}

The Appendix is available online: http://dx.doi.org/10.1890/14-1311.1.sm 